\title{
Total Phenolic Concentration and Browning Susceptibility in a Collection of Different Varietal Types and Hybrids of Eggplant: Implications for Breeding for Higher Nutritional Quality and Reduced Browning
}

\author{
Jaime Prohens ${ }^{1}$, Adrián Rodríguez-Burruezo, María Dolores Raigón, and Fernando Nuez \\ Instituto de Conservación y Mejora de la Agrodiversidad Valenciana, Universidad Politécnica de \\ Valencia, Camino de Vera 14, 46022 Valencia, Spain
}

AdDitional Index wORDs. Solanum melongena, fruit quality, selection, germplasm evaluation, commercial varieties

\begin{abstract}
Phenolic compounds have numerous beneficial effects on human health. In consequence, the development of new varieties with higher content of phenolics is of interest for the improvement of the nutritional quality of eggplant (Solanum melongena L.). However, the oxidation of eggplant phenolics causes browning of the cut surfaces of the fruit and reduces its apparent quality. The authors investigated the relationship among, as well as the variation and heritability of, the content of phenolics, ascorbic acid, and soluble solids; $\mathrm{pH}$; and the degree of browning and color difference of the cut surface of the fruit flesh in a collection of 69 eggplant varieties. These included landraces from different origins, commercial varieties, experimental hybrids, and four accessions of the related $S$. aethiopicum L. and $S$. macrocarpon L. species. Analyses of variance revealed significant differences among the materials studied for all traits considered. The concentration of phenolics in $S$. melongena spanned a threefold range, although the highest $\left(1122 \mathrm{mg} \cdot \mathrm{kg}^{-1}\right)$ and lowest $\left(134 \mathrm{mg} \cdot \mathrm{kg}^{-1}\right)$ concentrations of phenolics were found in $S$. macrocarpon and $S$. aethiopicum respectively. Concentrations of ascorbic acid were very low, a mean 27 times lower than those of phenolics, and soluble solids content ranged from $3.60 \%$ to $6.60 \%$ with a $\mathrm{pH}$ that ranged from 5.01 to 5.93 . Commercial varieties had, as a mean, a $20 \%$ lower concentration of phenolics than landraces, as well as a lower degree of browning and color difference. Positive correlations existed between phenolic concentration and degree of browning $(r=0.388)$ and color difference $(0.477)$, although only $15.1 \%$ and $22.8 \%$ of the total variation in degree of browning and color difference, respectively, could be attributed to variation in phenolics. Ascorbic acid, soluble solids content, and $\mathrm{pH}$ were not correlated to either degree of browning or color difference. The heritability was moderate for phenolic concentration (0.50) and high for degree of browning (0.71) and color difference (0.82). The information obtained indicates that there are opportunities for the development of new varieties with a high concentration of phenolics and low or moderate browning.
\end{abstract}

Eggplant has a high antioxidant capacity (Cao et al., 1996), and this is attributed to its high content in phenolic compounds. The main class of phenolics in eggplant includes hydroxycinnamic acid conjugates (Whitaker and Stommel, 2003) and, of these, chlorogenic acid (5-O-caffeoylquinic acid and its isomers) typically accounts for $70 \%$ to $95 \%$ of total phenolics in eggplant fruit flesh (Stommel and Whitaker, 2003). The beneficial effects on health of chlorogenic acid and related compounds present in minor quantities in eggplant are numerous, and apart from their potent antioxidant activity, they also include free radical scavenging and antitumoral activities (Sawa et al., 1998; Triantis et al., 2005).

The selection of eggplant accessions with an increased concentration of phenolics as a way to develop new varieties

Received for publication 22 Dec. 2006. Accepted for publication 4 May 2007 We thank John Stommel and Marie Christine Daunay for their reviews and comments on the original manuscript; Enric Regidor Perona, Enrique Calatayud Grancha, and Mariola Plazas Ávila for their help with analysis of samples; and Instituto Nacional de Investigación y Tecnología Agroalimentaria (INIA) (RF2004-00002-00-00), Ministerio de Ciencia y Tecnología (AGL200303949 and AGL2006-04878) and the European Union (RESGEN PL98-113) for funding this research.

${ }^{1}$ Corresponding author. E-mail: jprohens@btc.upv.es. with improved nutritional quality was suggested by Stommel and Whitaker (2003). These authors studied the concentration of hydroxycinnamic acid conjugates in the fruit flesh in a core collection of eggplant and found considerable variation, with a difference of almost fourfold among the varieties with highest and lowest concentrations. This indicates that there are ample possibilities for developing new commercial varieties with an increased concentration of phenolic compounds.

However, a drawback of increasing the concentration of these antioxidants in eggplant is that the oxidation of phenolics causes the browning of the fruit flesh after its exposure to the air, and this may lead to a reduction in the apparent quality (Macheix et al., 1990). When a fruit is cut, either for home consumption or for industrial processing, the destruction of fruit cellular compartmentation allows the orthodiphenolic substrates (hydroxycinnamic acid derivatives) to be accessible to polyphenol oxidases, which catalyze their oxidation to quinones, which react nonenzymatically with $\mathrm{O}_{2}$, sulfhydryl compounds, amines, amino acids, and proteins to give browncolored compounds (Ramírez et al., 2002). The activity of polyphenol oxidases varies among eggplant varieties (Dogan et al., 2002), which suggests that selection for a combined high concentration of phenolics and low browning should be 
feasible. Other factors, like intracellular $\mathrm{pH}$, which affects the activity of the polyphenol oxidase (PPO) enzymes (Concellón et al., 2004; Dogan et al., 2002), or the presence of ascorbic acid in the fruit flesh tissues, which prevents the oxidation of orthodiphenols (Macheix et al., 1990), might also have a role in the modification of the browning process in eggplant. Given the preference of consumers and the industry for varieties with white flesh and a low degree of browning (Prohens et al., 2005), new varieties with a high content of phenolics should also have a moderate flesh browning.

Apart from the variation existing in the eggplant types traditionally grown in Europe, America, western Asia, and Africa, there are other varieties corresponding to eastern Asian materials that have different plant and fruit characteristics (Daunay et al., 1997; Hallard, 1996; Lester and Hasan, 1991) and that could be sources of variation for a high content of phenolics, low browning, or both. Also, the gboma eggplant (Solanum macrocarpon) and scarlet eggplant (S. aethiopicum), which are cultivated species related to $S$. melongena (Sakata and Lester, 1997), mainly grown in Africa, but also in other parts of the world, like the case of scarlet eggplant in southern Italy (Polignano et al., 2004), could be useful for the genetic improvement of eggplant. Both species hybridize with the common eggplant (Ano et al., 1991; Bletsos et al., 2004), and might represent genetic resources of interest for the improvement of the quality of the common eggplant and for other traits like resistance to diseases (Gisbert et al., 2006). All these materials contain important genetic diversity for concentrations of hydroxycinnamic acid conjugates (Stommel and Whitaker, 2003).

During this investigation we determined the variation in phenolic concentration and fruit flesh browning in a collection of eggplant from different varietal types, the relationship between both traits, and the effects of other physicochemical traits on browning of eggplant. The use of a set of hybrids and their respective parents also allowed us to obtain information on the heritability of phenolic concentration and browning-related traits in eggplant. This is of interest for breeding new eggplant varieties that combine an improved nutritive value with a low degree of browning.

\section{Material and Methods}

Plant material. Materials used consisted of 69 varieties of $S$. melongena, two of S. aethiopicum, and two of S. macrocarpon (Table 1). Among the $S$. melongena varieties there were materials corresponding to different varietal types: landraces of Spanish $(n=18)$, African $(n=8)$, and Caribbean $(n=1)$ origins; European commercial hybrids $(\mathrm{n}=6)$; commercial nonhybrid varieties $(n=6)$; materials of southeast Asian origin $(n=6)$; and experimental hybrids obtained between parents included in the study $(n=24)$. These materials were chosen to represent the genetic diversity of eggplant. Experimental hybrids were included to obtain information on the heritability of the traits studied, which is of great relevance for the eggplant breeding programs. Solanum aethiopicum and $S$. macrocarpon are cultivated species mainly grown in Africa and are related to the common eggplant (Daunay and Lester, 1988).

Seeds of all materials were put to germinate in Petri dishes in May 2004. Germinated seeds were subsequently transferred to seedling trays and, at the beginning of July 2004, five plants per variety were transplanted in a completely randomized design to a field plot (sandy loamy soil) in the campus of the Universidad
Table 1. Varieties of common eggplant (Solanum melongena), scarlet eggplant ( $S$. aethiopicum), and gboma eggplant (S. macrocarpon) used in a study of total phenolic concentration and browning susceptibility.

\begin{tabular}{|c|c|c|}
\hline Variety & Origin & Fruit type \\
\hline \multicolumn{3}{|c|}{ Spanish landraces } \\
\hline ALM1 & Castilla-La Mancha, Spain & Semilong \\
\hline ANS3 & Andalucía, Spain & Semilong \\
\hline ANS6 & Andalucía, Spain & Round \\
\hline ANS24 & Andalucía, Spain & Semilong \\
\hline ANS26 & Andalucía, Spain & Semilong \\
\hline ART1 & Castilla-La Mancha, Spain & Semilong \\
\hline CS16 & Cataluña, Spain & Long \\
\hline IVIA25 & $\begin{array}{l}\text { Comunidad Valenciana, } \\
\text { Spain }\end{array}$ & Striped \\
\hline IVIA371 & $\begin{array}{l}\text { Comunidad Valenciana, } \\
\text { Spain }\end{array}$ & Striped \\
\hline IVIA400 & $\begin{array}{l}\text { Comunidad Valenciana, } \\
\text { Spain }\end{array}$ & Striped \\
\hline IVIA604 & $\begin{array}{l}\text { Comunidad Valenciana, } \\
\text { Spain }\end{array}$ & Striped \\
\hline MUR1 & Murcia, Spain & Round \\
\hline MUS3 & Murcia, Spain & Striped \\
\hline MUS8 & Murcia, Spain & Round \\
\hline VS3 & $\begin{array}{l}\text { Comunidad Valenciana, } \\
\text { Spain }\end{array}$ & Semilong \\
\hline VS9 & $\begin{array}{l}\text { Comunidad Valenciana, } \\
\text { Spain }\end{array}$ & Round \\
\hline VS10 & $\begin{array}{l}\text { Comunidad Valenciana, } \\
\text { Spain }\end{array}$ & Semilong \\
\hline VS22 & $\begin{array}{l}\text { Comunidad Valenciana, } \\
\text { Spain } \\
\text { African landraces }\end{array}$ & Striped \\
\hline Balady & Egypt & Semilong \\
\hline BBS118 & Ivory Coast & Semilong \\
\hline BBS175 & Ivory Coast & Semilong \\
\hline BBS186 & Ivory Coast & Semilong \\
\hline BBS189 & Ivory Coast & Semilong \\
\hline BBS190 & Ivory Coast & Semilong \\
\hline BBS191 & Ivory Coast & Semilong \\
\hline Rami & $\begin{array}{l}\text { Egypt } \\
\text { Caribbean landraces }\end{array}$ & Semilong \\
\hline SUDS5 & $\begin{array}{l}\text { Havana, Cuba } \\
\text { Commercial hybrids (European) }\end{array}$ & Semilong \\
\hline $10-201 \mathrm{~F}_{1}$ & $\begin{array}{l}\text { Rijk Zwaan B.V., De Lier, } \\
\text { The Netherlands }\end{array}$ & Semilong \\
\hline $10-501 \mathrm{~F}_{1}$ & Rijk Zwaan B.V. & Semilong \\
\hline Calanda $\mathrm{F}_{1}$ & $\begin{array}{l}\text { Ramiro Arnedo S.A., Calahorra, } \\
\text { Spain }\end{array}$ & Semilong \\
\hline Ecavi $\mathrm{F}_{1}$ & Rijk Zwaan B.V. & Semilong \\
\hline Mulata $\mathrm{F}_{1}$ & Ramiro Arnedo S.A. & Semilong \\
\hline Petra $F_{1}$ & $\begin{array}{l}\text { Semillas Fitó S.A., Barcelona, } \\
\text { Spain }\end{array}$ & Semilong \\
\hline \multicolumn{3}{|c|}{ Commercial nonhybrid varieties and breeding lines (European) } \\
\hline Black Beauty & Vilmorin, La Ménitré, France & Semilong \\
\hline Dourga & $\begin{array}{l}\text { Institut National } \\
\text { de la Recherche } \\
\text { Agronomique, Paris (INRA) }\end{array}$ & Long \\
\hline De Barbentane & Vilmorin & Long \\
\hline Larga Negra & Ramiro Arnedo S.A. & Long \\
\hline
\end{tabular}


Table 1. Continued.

\begin{tabular}{|c|c|c|}
\hline Variety & Origin & Fruit type \\
\hline LF3-24 & INRA & Long \\
\hline Listada de Gandía & $\begin{array}{l}\text { Semillas Clemente, } \\
\text { Vitoria, Spain } \\
\text { Asian materials }\end{array}$ & Striped \\
\hline ASIS1 & Beijing, China & Round \\
\hline Kermit & Thailand & Round \\
\hline Kurome & Japan & Long \\
\hline $\begin{array}{l}\text { Long White } \\
\text { Angel }\end{array}$ & China & Long \\
\hline Thai Long Green & Thailand & Long \\
\hline Thai Round Green & $\begin{array}{l}\text { Thailand } \\
\text { Experimental hybrids }\end{array}$ & Round \\
\hline H1 & IVIA25 × IVIA371 & Striped \\
\hline $\mathrm{H} 2$ & IVIA371 × IVIA25 & Striped \\
\hline H5 & ANS $6 \times$ ASIS 1 & Round \\
\hline H6 & ANS24 × ASIS 1 & Semilong \\
\hline $\mathrm{H} 7$ & ANS26 $\times$ ANS3 & Semilong \\
\hline H8 & ANS26 × VS22 & Long \\
\hline H9 & $\mathrm{ASIS} 1 \times \mathrm{ANS} 24$ & Semilong \\
\hline $\mathrm{H} 10$ & ASIS1 $1 \times$ SUDS5 & Round \\
\hline H11 & ASIS $1 \times$ VS 9 & Round \\
\hline H12 & CS16 $\times$ ASIS 1 & Semilong \\
\hline H13 & IVIA25 $\times$ ANS24 & Semilong \\
\hline H14 & IVIA371 $\times$ MUS8 & Semilong \\
\hline H15 & IVIA604 × VS22 & Semilong \\
\hline H16 & MUS3 × ANS3 & Semilong \\
\hline H17 & MUS8 × ANS6 & Semilong \\
\hline H18 & MUS8 × IVIA371 & Semilong \\
\hline H19 & MUS8 $\times$ IVIA400 & Semilong \\
\hline $\mathrm{H} 20$ & MUS8 × SUDS5 & Semilong \\
\hline $\mathrm{H} 21$ & MUS8 $\times$ VS9 & Round \\
\hline $\mathrm{H} 22$ & MUS $8 \times$ VS10 & Semilong \\
\hline $\mathrm{H} 24$ & VS9 $\times$ IVIA 25 & Semilong \\
\hline H26 & VS9 × MUS8 & Semilong \\
\hline $\mathrm{H} 27$ & VS9 $\times$ SUDS5 & Semilong \\
\hline $\mathrm{H} 28$ & $\begin{array}{l}\text { VS9 } \times \text { VS } 22 \\
\text { Solanum aethiopicum }\end{array}$ & Semilong \\
\hline BBS157 & Ivory Coast & Round \\
\hline BBS159 & $\begin{array}{l}\text { Ivory Coast } \\
\text { S. macrocarpon }\end{array}$ & Round \\
\hline BBS171 & Ivory Coast & Round \\
\hline BBS196 & Ivory Coast & Round \\
\hline
\end{tabular}

${ }^{\mathrm{z}}$ The round, semilong, and long types considered here are distinguished by the length-to-breadth ratio of the fruit $(\approx 1$ for the round, $>1.2$ and $<2$ for the semilong, and $>2$ for the long) and are characterized for presenting either uniform fruit color or a secondary color distributed in broad stripes. The striped (known as "listada" in Spain) type is typical of the Spanish Mediterranean region, and is characterized by an obovate to oblong shape and white or yellowish background color covered by narrow purple stripes.

Politécnica de Valencia, Valencia, Spain (GPS coordinates of the field plot: lat. $39^{\circ} 28^{\prime} 55^{\prime \prime} \mathrm{N}$, long. $\left.0^{\circ} 20^{\prime} 11^{\prime \prime} \mathrm{W}\right)$. A completely randomized design was used instead of a block design because the plot is quite uniform and previous experiments using block designs showed no block effect. Plants were spaced $1 \mathrm{~m}$ between rows and $0.4 \mathrm{~m}$ apart within the row and drip irrigated. The standard horticultural practices for eggplant in the Mediterranean coast of Spain (Baixauli, 2001) were followed. The fertilization, which consisted of $80 \mathrm{~g} / \mathrm{plant}$ of a commercial fertilizer of $10 \mathrm{~N}-2.2 \mathrm{P}-24.9 \mathrm{~K}$ plus micronutrients (Hakaphos Naranja; Compo Agricultura, Barcelona, Spain), was applied with the drip irrigation system. Fruit harvesting began 6 weeks after transplant.

EXPERIMENTAL DESIGN AND PREPARATION OF SAMPLES. Each plant was considered as a replication (i.e., five replications per variety), from which a single value was obtained for statistical analysis. For the chemical composition traits, a single measurement was made per replication, whereas for fruit flesh browning, several fruit per plant were measured (subsamples) and used for obtaining a mean value for each replication. Between two and seven fruit (depending on the fruit size) per plant were collected at commercial maturity (evaluated by the color and glossiness of the fruit skin and confirmed by the lack of seeds in the last stages of development) and brought to the laboratory, where they were washed and cut transversally for the measurement of the color of the flesh and its degree of browning after $10 \mathrm{~min}$. After that, fruit were peeled and a longitudinal section, consisting of a triangular slice with the base (between 1 and $3 \mathrm{~cm}$ depending on the size of the fruit) being close to the peel and the tip being the center of the fruit, from peduncle to blossom scar was taken for each fruit. The fruit sections of each individual plant were bulked and squeezed in a domestic juice extractor. Immediately after juice extraction, $5 \mathrm{~mL}$ of the homogenate corresponding to each plant were poured on $10 \mathrm{~mL}$ of an extracting solution of acetone $(70 \% \mathrm{v} / \mathrm{v})$ and glacial acetic acid $(0.5 \% \mathrm{v} / \mathrm{v})$ and left for $24 \mathrm{~h}$ at room temperature for extraction of phenolics. Another aliquot of 5 $\mathrm{mL}$ of juice homogenate was also quickly poured on $10 \mathrm{~mL}$ of a solution of metaphosphoric acid $(3 \% \mathrm{w} / \mathrm{v})$ and acetic acid $(8 \%$ $\mathrm{v} / \mathrm{v}$ ) for the immediate ascorbic acid concentration determination. The rest of the juice was used for the determination of soluble solids content (SSC) and for the measurement of $\mathrm{pH}$.

Measurements. Fruit flesh color was measured with a Minolta chroma-meter (CR-300; Minolta Co. Ltd., Osaka, Japan), fitted with an 8-mm-diameter aperture and expressed in the "CIELAB 1976 color coordinates." Fruit were cut transversally at the midpoint between the blossom and stem ends, and measurements were made in the central part immediately after being cut $(0 \mathrm{~min})$ and $10 \mathrm{~min}$ later. A wellsharpened knife with a straight edge was used to produce clean cuts. The whiteness of the fruit flesh was measured as the Euclidean distance of the color coordinates to the pure white color coordinates $\left(L^{*}=100, a^{*}=0, b^{*}=0\right)$ using the formula

$$
\left.\mathrm{DW}=\left[\left(100-\mathrm{L}^{*}\right)^{2}+\mathrm{a}^{*^{2}}+\mathrm{b}^{* 2}\right)\right]^{0.5}
$$

where DW is the distance to the pure white color. The difference between $\mathrm{DW}$ at $10 \mathrm{~min}\left(\mathrm{DW}_{10}\right)$ and at $0 \mathrm{~min}$ after the fruit was cut $\left(\mathrm{DW}_{0}\right.$; i.e., the increase in the distance to pure white) was used as a measure of degree of browning suffered by the fruit (degree of browning $=\mathrm{DW}_{10}-\mathrm{DW}_{0}$ ). The color difference was measured as the Euclidean distance between the color coordinates at 0 and $10 \mathrm{~min}$ after the cut:

$$
\mathrm{CD}=\left[\left(\mathrm{L}^{*}{ }_{10}-\mathrm{L} *_{0}\right)^{2}+\left(\mathrm{a} *_{10}-\mathrm{a}^{*}\right)^{2}+\left(\mathrm{b} *_{10}-\mathrm{b}^{*}{ }_{0}\right)^{2}\right]^{0.5}
$$

Both measures give different and complementary information related to the evolution of color.

Phenolic content was determined according to the FolinCiocalteu procedure (Singleton and Rossi, 1965). An aliquot of $1.25 \mathrm{~mL}$ of the extracted phenolic sample was centrifuged at 
$8050 g_{\mathrm{n}}$ for $5 \mathrm{~min}$ and $65 \mu \mathrm{L}$ of the supernatant were mixed with $0.5 \mathrm{~mL}$ diluted $(10 \% \mathrm{v} / \mathrm{v})$ Folin-Ciocalteu reagent (SigmaAldrich Chemie, Steinheim, Germany) and allowed to stand at room temperature for $5 \mathrm{~min} ; 0.50 \mathrm{~mL}$ of a sodium carbonate solution $\left(60 \mathrm{~g} \cdot \mathrm{L}^{-1}\right)$ was added to the mixture. After $90 \mathrm{~min}$ at room temperature, absorbance was measured at 725 and also at $760 \mathrm{~nm}$ in a UV-VIS spectrophotometer (Lambda 25; PerkinElmer, Madrid, Spain). Chlorogenic acid (Sigma-Aldrich Chemie) was used as a standard. The phenolic acid content was expressed as chlorogenic acid equivalents in milligrams per kilogram fresh fruit.

Ascorbic acid concentration (milligrams per kilogram) was determined by titrating the diluted $(15 \% \mathrm{v} / \mathrm{v})$ extracted juice with 2,6-dichlorophenolindolephenol dye. Soluble solids content was measured in the supernatant of a centrifuged $\left(8050 \mathrm{~g}_{\mathrm{n}}\right.$ for $5 \mathrm{~min}$ ) sample of juice with a hand-held refractometer (N-8 $\alpha$; Atago Co. Ltd., Tokyo, Japan). The $\mathrm{pH}$ of the juice was measured with a digital pH meter (MP 220; Mettler Toledo, Barcelona, Spain).

Statistical analyses. Data were subjected to factorial analysis of variance (ANOVA) using a fixed-effects model for the effect of variety. The average (pooled) SE for each trait was obtained from the corresponding ANOVA. Linear correlation coefficients $(r)$ between traits were calculated from regression analyses between pairs of traits. The coefficients of determination $\left(r^{2}\right)$, which measure the variability explained by the linear regression, were also computed and expressed in percentage. Solanum aethiopicum and $S$. macrocarpon were excluded from the regression analyses to avoid the appearance of spurious correlations resulting from the mixture of heterogeneous materials (Aldrich, 1995). Additional regression analyses were used to obtain the regression coefficient $(b)$ of the means of experimental hybrids over midparent values for each trait. In our case, the value of $b$ represents an estimate of the narrow-sense heritability $\left(\mathrm{h}^{2}\right)$, which is an important parameter in the efficiency of selection in crossing programs (Wricke and Weber, 1986). All statistics were conducted using specific software (Statgraphics Plus 5.1, Statistical Graphics Corp., Rockville, MD).

\section{Results}

Phenolics. The correlation coefficient between the concentration of phenolics determined at 725 or $760 \mathrm{~nm}$ was very high $(r=0.985 ; P<0.001)$. Therefore, the phenolic concentration of each sample was calculated as the mean between the estimates at 725 and $760 \mathrm{~nm}$.

Large differences in phenolic concentration were found among the materials studied, with a range from $134 \mathrm{mg} \cdot \mathrm{kg}^{-1}$ in $S$. aethiopicum BBS157 to $1122 \mathrm{mg} \cdot \mathrm{kg}^{-1}$ in $S$. macrocarpon BBS196 (i.e., a difference of more than eightfold; Table 2). When considering only the $S$. melongena materials, the range goes from $280 \mathrm{mg} \cdot \mathrm{kg}^{-1}$ ('Listada de Gandía') to $834 \mathrm{mg} \cdot \mathrm{kg}^{-1}$ (ALM1), which represents a difference of almost threefold. The range of variation within each varietal type is also high, and within each varietal type of $S$. melongena (except for the Caribbean type, which consists of a single variety) there are varieties with relatively high and low phenolic concentrations. However, it is noteworthy that the $S$. melongena varieties with a greater concentration of phenolics are included within the groups of Spanish and African landraces as well as among experimental hybrids and Asian materials, but not in the
Table 2. Mean values and average (pooled) SE (see last line of the table) for the concentrations of phenolics, ascorbic acid, soluble solids content (SSC), and $\mathrm{pH}$ of the eggplant varieties studied, grouped by varietal type.

\begin{tabular}{|c|c|c|c|c|}
\hline Variety & Phenolics $\left(\mathrm{mg} \cdot \mathrm{kg}^{-1}\right)$ & $\begin{array}{c}\text { Ascorbic } \\
\text { acid }\left(\mathrm{mg} \cdot \mathrm{kg}^{-1}\right)\end{array}$ & $\mathrm{SSC}(\%)$ & $\mathrm{pH}$ \\
\hline \multicolumn{5}{|c|}{ Spanish landraces } \\
\hline ALM1 & 834 & 17.3 & 5.20 & 5.08 \\
\hline ANS3 & 765 & 21.7 & 6.49 & 5.31 \\
\hline ANS6 & 409 & 17.8 & 5.20 & 5.42 \\
\hline ANS24 & 752 & 19.1 & 5.74 & 5.55 \\
\hline ANS26 & 524 & 18.1 & 4.64 & 5.40 \\
\hline ART1 & 394 & 17.6 & 4.06 & 5.37 \\
\hline CS16 & 332 & 18.8 & 4.82 & 5.42 \\
\hline IVIA25 & 426 & 19.2 & 4.10 & 5.54 \\
\hline IVIA371 & 556 & 16.2 & 6.07 & 5.23 \\
\hline IVIA400 & 438 & 15.5 & 4.50 & 5.53 \\
\hline IVIA604 & 509 & 17.0 & 5.80 & 5.35 \\
\hline MUR1 & 483 & 15.2 & 4.52 & 5.07 \\
\hline MUS3 & 314 & 17.5 & 4.64 & 5.65 \\
\hline MUS8 & 344 & 20.2 & 5.00 & 5.24 \\
\hline VS3 & 656 & 15.1 & 4.58 & 5.22 \\
\hline VS9 & 521 & 21.2 & 5.38 & 5.34 \\
\hline VS10 & 404 & 18.6 & 3.68 & 5.29 \\
\hline VS22 & 401 & 15.5 & 6.40 & 5.13 \\
\hline \multicolumn{5}{|c|}{ African landraces } \\
\hline Balady & 524 & 17.6 & 4.72 & 5.20 \\
\hline BBS118 & 461 & 15.7 & 4.28 & 5.18 \\
\hline BBS175 & 718 & 13.8 & 5.00 & 5.40 \\
\hline BBS186 & 526 & 10.5 & 3.72 & 5.20 \\
\hline BBS189 & 480 & 10.3 & 5.28 & 5.29 \\
\hline BBS190 & 630 & 12.8 & 5.00 & 5.31 \\
\hline BBS191 & 561 & 11.5 & 4.30 & 5.01 \\
\hline Rami & 429 & 11.8 & 5.22 & 5.25 \\
\hline \multicolumn{5}{|c|}{ Caribbean landraces } \\
\hline SUDS5 & 335 & 20.1 & 5.23 & 5.23 \\
\hline \multicolumn{5}{|c|}{ Commercial hybrids (European) } \\
\hline $10-201$ & 356 & 16.4 & 4.18 & 5.45 \\
\hline $10-501$ & 507 & 17.6 & 4.00 & 5.45 \\
\hline Calanda & 420 & 17.4 & 5.02 & 5.21 \\
\hline Ecavi & 517 & 17.2 & 4.06 & 5.27 \\
\hline Mulata & 417 & 18.7 & 4.42 & 5.39 \\
\hline Petra & 391 & 17.4 & 4.50 & 5.43 \\
\hline \multicolumn{5}{|c|}{ Commercial nonhybrid varieties (European) } \\
\hline Black Beauty & 409 & 17.8 & 5.50 & 5.12 \\
\hline Dourga & 356 & 11.0 & 4.60 & 5.19 \\
\hline De Barbentane & 464 & 18.5 & 4.60 & 5.45 \\
\hline Larga Negra & 459 & 21.0 & 5.38 & 5.37 \\
\hline LF3-24 & 292 & 10.0 & 4.38 & 5.36 \\
\hline Listada de Gandía & 280 & 11.6 & 3.60 & 5.45 \\
\hline \multicolumn{5}{|c|}{ Asian materials } \\
\hline ASIS1 & 424 & 19.8 & 5.32 & 5.46 \\
\hline Kermit & 556 & 16.1 & 5.20 & 5.58 \\
\hline Kurome & 321 & 14.2 & 5.32 & 5.24 \\
\hline Long White & 318 & 13.1 & 4.10 & 5.18 \\
\hline Angel & & & & \\
\hline Thai Long & 442 & 21.7 & 5.50 & 5.35 \\
\hline Green & & & & \\
\hline Thai Round & 716 & 14.4 & 5.38 & 5.51 \\
\hline
\end{tabular}


Table 2. Continued.

\begin{tabular}{|c|c|c|c|c|}
\hline Variety & Phenolics $\left(\mathrm{mg} \cdot \mathrm{kg}^{-1}\right)$ & $\begin{array}{c}\text { Ascorbic } \\
\text { acid }\left(\mathrm{mg} \cdot \mathrm{kg}^{-1}\right)\end{array}$ & $\mathrm{SSC}(\%)$ & $\mathrm{pH}$ \\
\hline \multicolumn{5}{|c|}{ Experimental hybrids } \\
\hline H1 & 428 & 18.7 & 4.87 & 5.09 \\
\hline $\mathrm{H} 2$ & 522 & 20.0 & 6.44 & 5.27 \\
\hline H5 & 460 & 15.5 & 4.82 & 5.38 \\
\hline H6 & 401 & 13.2 & 5.20 & 5.45 \\
\hline H7 & 474 & 20.0 & 5.60 & 5.45 \\
\hline H8 & 422 & 19.6 & 6.00 & 5.48 \\
\hline H9 & 387 & 13.6 & 6.12 & 5.31 \\
\hline H10 & 391 & 19.2 & 5.54 & 5.32 \\
\hline H11 & 472 & 19.9 & 6.36 & 5.43 \\
\hline H12 & 373 & 17.5 & 5.20 & 5.40 \\
\hline H13 & 524 & 17.1 & 6.60 & 5.31 \\
\hline H14 & 448 & 16.2 & 4.86 & 5.38 \\
\hline H15 & 406 & 16.6 & 4.96 & 5.21 \\
\hline H16 & 742 & 17.4 & 4.98 & 5.52 \\
\hline H17 & 409 & 21.3 & 4.92 & 5.24 \\
\hline H18 & 336 & 17.0 & 4.66 & 5.08 \\
\hline H19 & 337 & 17.8 & 4.76 & 5.19 \\
\hline $\mathrm{H} 20$ & 333 & 17.2 & 4.82 & 5.24 \\
\hline $\mathrm{H} 21$ & 434 & 21.3 & 4.80 & 5.36 \\
\hline $\mathrm{H} 22$ & 389 & 18.4 & 4.26 & 5.35 \\
\hline $\mathrm{H} 24$ & 542 & 19.8 & 5.34 & 5.25 \\
\hline H26 & 477 & 20.2 & 4.40 & 5.41 \\
\hline $\mathrm{H} 27$ & 339 & 18.8 & 4.90 & 5.36 \\
\hline $\mathrm{H} 28$ & 520 & 21.0 & 5.38 & 5.54 \\
\hline \multicolumn{5}{|c|}{ Solanum aethiopicum } \\
\hline BBS157 & 134 & 16.5 & 5.80 & 5.70 \\
\hline BBS159 & 191 & 22.6 & 5.50 & 5.93 \\
\hline \multicolumn{5}{|c|}{ S. macrocarpon } \\
\hline BBS171 & 544 & 17.7 & 4.60 & 5.54 \\
\hline BBS196 & 1122 & 19.6 & 5.86 & 5.42 \\
\hline Average SE & 35 & 0.6 & 0.34 & 0.05 \\
\hline
\end{tabular}

The average SE has been obtained from the mean square error from the analysis of variance for one factor (variety).

SSC, soluble solids content.

European commercial varieties (Table 2). The greatest values among the European commercial hybrids and commercial nonhybrids were 507 and $464 \mathrm{mg} \cdot \mathrm{kg}^{-1}$ respectively. When we consider the landraces on one side and the European commercial materials on the other, the landraces have a significantly greater $(\mathrm{t}=2.394 ; P=0.022)$ mean for the phenolic concentration $\left(509 \mathrm{mg} \cdot \mathrm{kg}^{-1}\right)$ than commercial materials $\left(406 \mathrm{mg} \cdot \mathrm{kg}^{-1}\right)$.

AscorbiC ACID, SOLUBLE SOLIDS CONTENT, AND PH. Ascorbic acid concentrations are much lower than those of phenolics and range between $10.0 \mathrm{mg} \cdot \mathrm{kg}^{-1}$ for $S$. melongena 'LF3-24' and $22.6 \mathrm{mg} \cdot \mathrm{kg}^{-1}$ for $S$. aethiopicum BBS159 (Table 2). A wide range of variation exists within each $S$. melongena varietal type. However, it is noteworthy that most of the African landraces have relatively low ascorbic acid concentrations in comparison with the rest of the eggplant varieties (Table 2). Similar to what occurs for the phenolic and ascorbic acid concentrations, an important variation has been found for SSC in the materials studied, as well as within each varietal type (Table 2). However, in this case, both the maximum and minimum values are encountered in S. melongena $3.60 \%$ in 'Listada de Gandía' and $6.60 \%$ in $\mathrm{H} 13)$. The $\mathrm{pH}$ of the materials studied ranges between 5.01 for $S$. melongena BBS191 and 5.93 for $S$. aethiopicum BBS159 (Table 2). The two accessions of the latter species showed the highest $\mathrm{pH}$ values of the whole experiment. When considering $S$. melongena alone, the maximum value for $\mathrm{pH}$ is 5.65 (MUS3). Although there is also variation within varietal types for this trait, there are many varieties among African landraces with relatively low $\mathrm{pH}$ values (Table 2 ).

Fruit FLESh COLOR AND BRowning. The values of $\mathrm{DW}_{0}$ for the fruit flesh were between 16.66 and 34.66 for $S$. melongena varieties BBS189 and 'De Barbentane,' respectively; whereas for $\mathrm{DW}_{10}$, they ranged from 20.43 for $S$. melongena 'Listada de Gandía' to 38.90 for $S$. macrocarpon BBS196 (Table 3). As for the other physicochemical traits, an important diversity is found within each varietal group for $\mathrm{DW}_{0}$ and $\mathrm{DW}_{10}$ (Table 3). However, it is noteworthy that the varieties with the lowest $\mathrm{DW}_{0}$ are included in the group of the African landraces.

Values for degree of browning among $S$. melongena materials range from 1.08 for Kurome to 7.92 for H16. As for the other traits, there is considerable variation within varietal types for browning. However, the European commercial types have, as a mean, a significantly $(\mathrm{t}=-2.760 ; P=0.009)$ lower degree of browning values (2.64) than the landraces (4.26). Regarding color difference, the range of values goes from 1.42 for $S$. aethiopicum BBS157 to 13.03 for S. macrocarpon BBS196. Similar to what occurred for degree of browning, European commercial types exhibit a significantly $(\mathrm{t}=-2.217 ; P=0.033)$ smaller change in color difference (3.81) than landraces (5.38).

Correlations Between Traits. Correlations between traits for $S$. melongena materials show that there are significant positive correlations of the phenolics with degree of browning and color difference (Table 4). Nonetheless, the percentage of the total variation in degree of browning and color difference explained by the variation in total phenolics (parameter $r^{2}$ ) is only $15.1 \%$ and $22.8 \%$ respectively, indicating that other factors contribute to a substantial portion of the variation in these traits. Consequently, it is possible to find varieties with a high concentration of phenolics and relatively low or intermediate degree of browning or color difference (Fig. 1). For example, ANS24 and Thai Round Green have a high content of phenolics (Table 2) and moderate degree of browning and color difference (Table 3). A positive weak correlation was also found between phenolics and SSC (Table 4). It is noteworthy that phenolic concentration was not correlated with $\mathrm{DW}_{0}$, which indicates that the color of the fruit flesh immediately after being cut does not depend on the phenolic content, and is related to other factors, like the presence of chlorophylls (Daunay et al., 2004). However, there is a weak, but significant, positive correlation between the concentration of phenolics and $\mathrm{DW}_{10}$. Correlations of phenolics with the ascorbic acid content and $\mathrm{pH}$ were nonsignificant (Table 4).

Ascorbic acid concentration was positively correlated with SSC and also with $\mathrm{DW}_{0}$ and $\mathrm{DW}_{10}$ (Table 4). However, ascorbic acid concentration is not correlated with degree of browning or color difference parameters. Similarly, $\mathrm{pH}$ is not correlated to any of these browning-related parameters (Table 4).

$\mathrm{DW}_{0}$ is positively correlated with $\mathrm{DW}_{10}(65.1 \%$ of the variation in $\mathrm{DW}_{10}$ explained by the variation in $\left.\mathrm{DW}_{0}\right)$, but there is no relationship of $\mathrm{DW}_{0}$ and degree of browning or color difference (Table 4), indicating that the color evolution change is independent of the initial value of the fruit flesh color. In contrast, $\mathrm{DW}_{10}$ is positively correlated with degree of browning 
Table 3. Mean values and average (pooled) SE (see last line of the table) for the Euclidean distance of the flesh color coordinates to pure white (DW) at $0\left(\mathrm{DW}_{0}\right)$ and $10 \mathrm{~min}\left(\mathrm{DW}_{10}\right)$ after the fruit has been cut, DB (degree of browning), and CD (color difference) of the eggplant varieties studied, grouped by varietal type.

\begin{tabular}{|c|c|c|c|c|}
\hline Variety & $\mathrm{DW}_{0}^{\mathrm{z}}$ & $\mathrm{DW}_{10}$ & DB & $\mathrm{CD}$ \\
\hline \multicolumn{5}{|c|}{ Spanish landraces } \\
\hline ALM1 & 26.89 & 31.54 & 4.65 & 6.37 \\
\hline ANS3 & 28.22 & 36.08 & 7.87 & 11.22 \\
\hline ANS6 & 23.46 & 26.81 & 3.35 & 4.04 \\
\hline ANS24 & 25.76 & 28.89 & 3.12 & 4.33 \\
\hline ANS26 & 22.87 & 24.48 & 1.61 & 2.62 \\
\hline ART1 & 25.20 & 30.12 & 4.92 & 6.23 \\
\hline CS16 & 28.66 & 30.88 & 2.22 & 3.79 \\
\hline IVIA25 & 28.74 & 32.42 & 3.68 & 4.49 \\
\hline IVIA371 & 21.94 & 27.54 & 5.60 & 6.33 \\
\hline IVIA400 & 20.62 & 21.95 & 1.32 & 1.61 \\
\hline IVIA604 & 21.50 & 25.44 & 3.93 & 4.25 \\
\hline MUR1 & 29.23 & 31.99 & 2.76 & 4.04 \\
\hline MUS3 & 24.03 & 31.86 & 7.83 & 8.74 \\
\hline MUS8 & 22.24 & 24.19 & 1.95 & 2.67 \\
\hline VS3 & 25.53 & 29.78 & 4.25 & 5.91 \\
\hline VS9 & 23.76 & 29.50 & 5.74 & 7.06 \\
\hline VS10 & 25.09 & 26.66 & 1.57 & 1.89 \\
\hline VS22 & 22.06 & 23.35 & 1.29 & 1.62 \\
\hline \multicolumn{5}{|c|}{ African landraces } \\
\hline Balady & 25.81 & 29.92 & 4.11 & 5.37 \\
\hline BBS118 & 17.95 & 23.95 & 6.00 & 6.58 \\
\hline BBS175 & 27.66 & 32.44 & 4.78 & 7.52 \\
\hline BBS186 & 16.66 & 24.76 & 7.27 & 7.90 \\
\hline BBS189 & 16.66 & 20.76 & 4.09 & 4.46 \\
\hline BBS190 & 17.93 & 22.25 & 4.31 & 5.84 \\
\hline BBS191 & 22.66 & 28.66 & 6.00 & 6.78 \\
\hline Rami & 21.78 & 25.52 & 3.74 & 4.94 \\
\hline \multicolumn{5}{|c|}{ Caribbean landraces } \\
\hline SUDS5 & 24.11 & 31.20 & 7.09 & 8.67 \\
\hline \multicolumn{5}{|c|}{ Commercial hybrids (European) } \\
\hline $10-201$ & 27.67 & 29.49 & 1.82 & 2.85 \\
\hline $10-501$ & 24.63 & 26.71 & 2.08 & 2.87 \\
\hline Calanda & 24.66 & 27.74 & 3.08 & 4.14 \\
\hline Ecavi & 28.42 & 31.27 & 2.85 & 4.28 \\
\hline Mulata & 26.58 & 29.68 & 3.11 & 4.24 \\
\hline Petra & 26.49 & 28.95 & 2.46 & 3.69 \\
\hline
\end{tabular}

Commercial nonhybrid varieties and breeding lines (European)

\begin{tabular}{lcccc} 
Black Beauty & 22.74 & 25.77 & 3.02 & 3.72 \\
Dourga & 22.91 & 27.29 & 4.38 & 4.92 \\
De Barbentane & 34.66 & 37.33 & 2.67 & 5.75 \\
Larga Negra & 29.64 & 31.79 & 2.15 & 4.34 \\
LF3-24 & 25.19 & 27.85 & 2.66 & 3.31 \\
Listada de Gandía & 19.07 & 20.43 & 1.36 & 1.57 \\
& \multicolumn{4}{c}{ Asian materials } \\
ASIS1 & 23.41 & 25.21 & 1.79 & \\
Kermit & 23.17 & 30.37 & 7.21 & 8.76 \\
Kurome & 33.82 & 34.90 & 1.08 & 3.78 \\
Long White & 27.07 & 29.43 & 2.36 & 3.25 \\
Angel & & & & \\
Thai Long & 33.95 & 35.97 & 2.02 & 4.98 \\
Green & & & & \\
Thai Round Green & 25.12 & 28.11 & 2.99 & 4.60
\end{tabular}

Table 3. Continued.

\begin{tabular}{|c|c|c|c|c|}
\hline Variety & $\mathrm{DW}_{0}^{\mathrm{z}}$ & $\mathrm{DW}_{10}$ & DB & $\mathrm{CD}$ \\
\hline \multicolumn{5}{|c|}{ Experimental hybrids } \\
\hline H1 & 19.21 & 23.02 & 3.82 & 4.08 \\
\hline $\mathrm{H} 2$ & 20.84 & 23.50 & 2.66 & 3.01 \\
\hline H5 & 22.50 & 23.71 & 1.21 & 2.01 \\
\hline H6 & 19.10 & 22.23 & 3.12 & 3.47 \\
\hline $\mathrm{H} 7$ & 26.60 & 31.89 & 5.29 & 7.26 \\
\hline H8 & 27.23 & 31.86 & 4.63 & 5.76 \\
\hline H9 & 21.43 & 23.22 & 1.79 & 2.30 \\
\hline $\mathrm{H} 10$ & 20.73 & 25.11 & 4.38 & 5.06 \\
\hline H11 & 24.29 & 27.65 & 3.37 & 4.87 \\
\hline H12 & 24.18 & 26.06 & 1.88 & 2.67 \\
\hline H13 & 29.81 & 37.42 & 7.60 & 8.99 \\
\hline H14 & 20.27 & 23.24 & 2.97 & 3.47 \\
\hline H15 & 21.25 & 22.91 & 1.66 & 2.08 \\
\hline H16 & 26.69 & 34.62 & 7.92 & 10.57 \\
\hline H17 & 22.41 & 25.28 & 2.87 & 3.64 \\
\hline H18 & 20.94 & 22.81 & 1.86 & 2.25 \\
\hline H19 & 20.40 & 22.54 & 2.14 & 2.50 \\
\hline $\mathrm{H} 20$ & 21.20 & 26.00 & 4.80 & 5.63 \\
\hline $\mathrm{H} 21$ & 23.98 & 27.03 & 3.05 & 4.13 \\
\hline $\mathrm{H} 22$ & 22.13 & 23.88 & 1.75 & 2.07 \\
\hline $\mathrm{H} 24$ & 20.80 & 24.44 & 3.64 & 4.06 \\
\hline $\mathrm{H} 26$ & 23.60 & 26.23 & 2.63 & 3.33 \\
\hline $\mathrm{H} 27$ & 23.32 & 27.89 & 4.57 & 5.40 \\
\hline $\mathrm{H} 28$ & 21.98 & 23.40 & 1.42 & 1.82 \\
\hline \multicolumn{5}{|c|}{ Solanum aethiopicum } \\
\hline BBS157 & 26.78 & 27.42 & 0.65 & 1.42 \\
\hline BBS159 & 28.92 & 28.90 & -0.02 & 5.65 \\
\hline \multicolumn{5}{|c|}{ S. macrocarpon } \\
\hline BBS171 & 29.86 & 35.17 & 5.31 & 10.42 \\
\hline BBS196 & 31.38 & 38.90 & 7.53 & 13.03 \\
\hline Average SE & 0.81 & 1.06 & 0.68 & 0.90 \\
\hline
\end{tabular}

$\left.{ }^{\mathrm{z}} \mathrm{DW}_{0}=\left[\left(100-\mathrm{L}_{0} *\right)^{2}+\mathrm{a}_{0}{ }^{* 2}+\mathrm{b}_{0}{ }^{* 2}\right)\right]^{0.5}, \mathrm{DW}_{0}=\left[\left(100-\mathrm{L}_{0} *\right)^{2}+\mathrm{a}_{0}{ }^{22}+\right.$ $\left.\left.\mathrm{b}_{0}{ }^{* 2}\right)\right]^{0.5}, \mathrm{DB}=\mathrm{DW}_{10}-\mathrm{DW}_{0}, \mathrm{CD}=\left[\left(\mathrm{L}^{*}{ }_{10}-\mathrm{L}^{*}\right)^{2}+\left(\mathrm{a}^{*}{ }_{10}-\mathrm{a}^{*}{ }_{0}\right)^{2}+\right.$ $\left.\left(\mathrm{b}_{10}-\mathrm{b}_{0}{ }^{2}\right)^{2}\right]^{0.5}$.

The average SE has been obtained from the mean square error from the analysis of variance for one factor (variety).

$\mathrm{CD}$, color difference; $\mathrm{DB}$, degree of browning; $\mathrm{DW}_{0}$, Euclidean distance of the fruit flesh color to pure white at $0 \mathrm{~min}$ after the fruit was cut; $\mathrm{DW}_{10}$, Euclidean distance of the fruit flesh color to pure white at $10 \mathrm{~min}$ after the fruit was cut.

and color difference (Table 4). Degree of browning and color difference present a high significant correlation. In fact, $89.7 \%$ of the variation in one of these traits is explained by the variation in the other trait.

Heritability. The coefficient of linear regression of hybrids over the midparent value (narrow-sense heritability) for phenolics is moderate $(0.50)$ and significant $(P<0.05)$, indicating that selection of parents with a high content of phenolics to obtain hybrids with a high content of these antioxidants will be efficient. However, the values of the heritability for ascorbic acid concentration, SSC, and $\mathrm{pH}$ are low $(<0.30)$ and nonsignificantly different from zero.

There is a high heritability in $\mathrm{DW}_{0}$ and $\mathrm{DW}_{10}$, with values of 0.64 and 0.79 respectively (i.e., the selection of parents with a low $\mathrm{DW}_{0}$ or $\mathrm{DW}_{10}$ will be efficient to obtain hybrids with low $\mathrm{DW}_{0}$ and $\mathrm{DW}_{10}$ values). Also, the browning-related parameters of degree of browning and color difference have 
Table 4. Coefficients of correlation between traits studied (above diagonal) and coefficients of determination (\%; below the diagonal) for the Solanum melongena materials studied.

\begin{tabular}{|c|c|c|c|c|c|c|c|c|}
\hline & Phenolics & Ascorbic acid & $\mathrm{SSC}$ & $\mathrm{pH}$ & $\mathrm{DW}_{0}$ & $\mathrm{DW}_{10}$ & DB & $\mathrm{CD}$ \\
\hline Phenolics & & $0.057 \mathrm{NS}$ & $0.281^{*}$ & $0.051 \mathrm{NS}$ & $0.094 \mathrm{NS}$ & $0.259^{*}$ & $0.388 * * *$ & $0.477 * * *$ \\
\hline Ascorbic acid & 0.3 & & $0.292 *$ & $0.220 \mathrm{NS}$ & $0.307^{*}$ & $0.258 *$ & $-0.033 \mathrm{NS}$ & $0.046 \mathrm{NS}$ \\
\hline $\mathrm{SSC}$ & 7.9 & 8.5 & & $0.016 \mathrm{NS}$ & $-0.035 \mathrm{NS}$ & $0.120 \mathrm{NS}$ & $0.172 \mathrm{NS}$ & $0.217 \mathrm{NS}$ \\
\hline $\mathrm{DW}_{0}$ & 0.9 & 9.4 & 0.1 & 3.6 & & $0.807 * * *$ & $-0.035 \mathrm{NS}$ & $0.148 \mathrm{NS}$ \\
\hline $\mathrm{DW}_{10}$ & 6.7 & 6.7 & 1.4 & 2.4 & 65.1 & & $0.415 * * *$ & $0.628 * * *$ \\
\hline DB & 15.1 & 0.1 & 3.0 & $<0.1$ & 0.1 & 17.2 & & $0.947 * * *$ \\
\hline
\end{tabular}

$\mathrm{Ns}^{*, * * * * * *}$ Nonsignificant at $P<0.05$ and significant at $P<0.05,<0.01$, and $<0.001$ respectively.

$\mathrm{CD}$, color difference; $\mathrm{DB}$, degree of browning; $\mathrm{DW}_{0}$, Euclidean distance of the fruit flesh color to pure white at 0 min after the fruit was cut; $\mathrm{DW}_{10}$, Euclidean distance of the fruit flesh color to pure white at $10 \mathrm{~min}$ after the fruit was cut; SSC = soluble solids content.
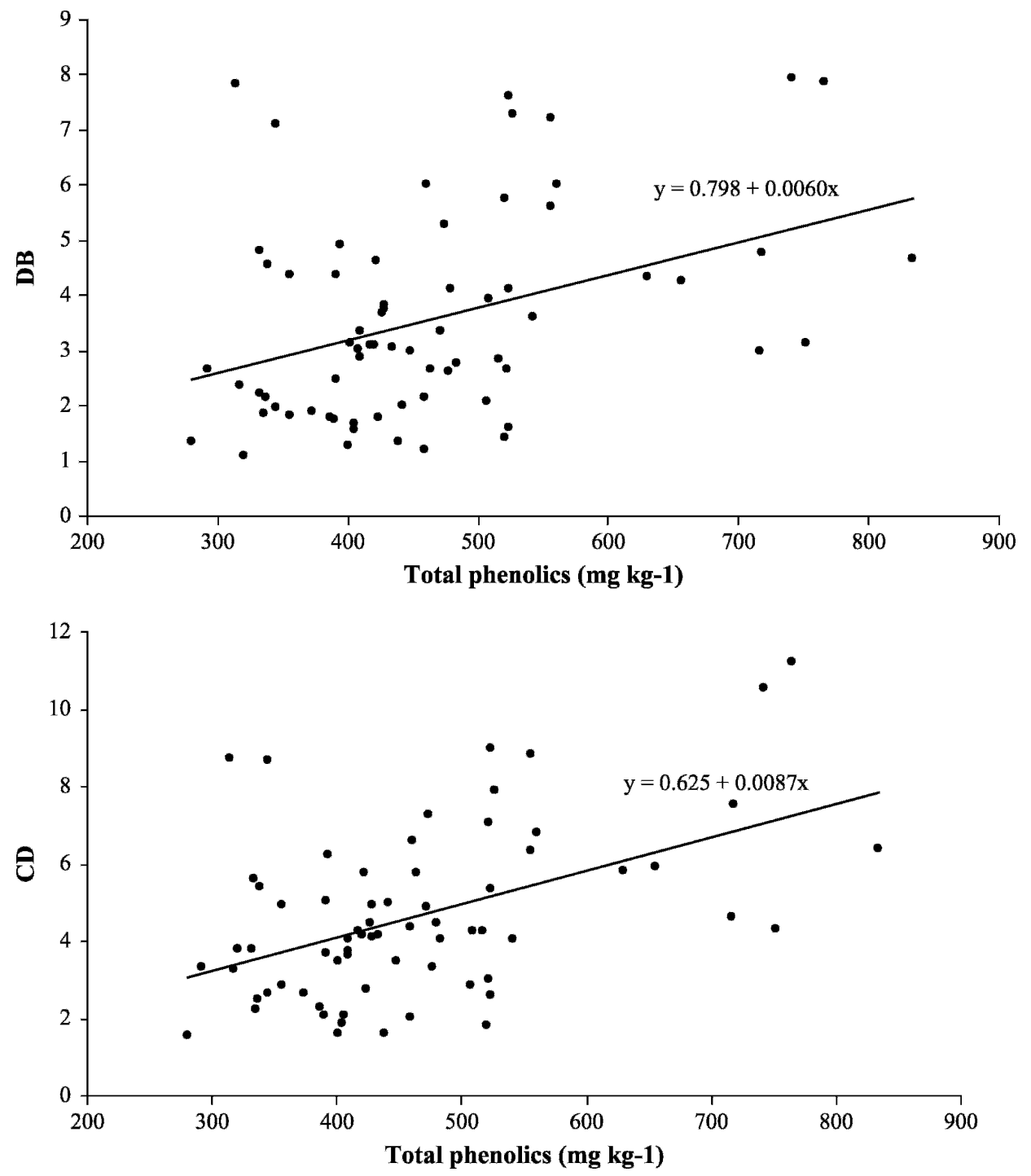

Fig. 1. Relationship among total phenolic content (measured in milligrams per kilogram) and the degree of browning [DB (above)] and color difference [CD (below)] of fruit flesh after exposure to the air for $10 \mathrm{~min}$ for the Solanum melongena materials studied.

high heritability values ( 0.71 and 0.82 respectively), indicating that parents that present a high degree of browning or color difference will give hybrids having high values for these traits.

\section{Discussion}

Our results confirm the findings of Stommel and Whitaker (2003) and Whitaker and Stommel (2003), demonstrating that there is a broad variation among $S$. melongena materials for phenolic concentration in the fruit flesh. This wide variation, together with the relatively high value of the heritability $(0.50)$ determined in a set of hybrids, indicates that breeding programs aimed at developing new varieties with higher phenolic concentrations may be successful. Unpublished results by our group with six varieties suggest that the content of phenolics is relatively stable among years, which indicates that genetic variation accounts for an important part of the diversity for this trait. The fact that chlorogenic acid is by far the predominant phenolic compound, suggests that an important part of the genetic variation may be the result of a few genetic factors involved in the biochemical pathways leading to the accumulation of chlorogenic acid (Niggeweg et al., 2004).

The modern commercial varieties used in our study (commercial hybrids and commercial nonhybrids) have, as a mean, a lower concentration of phenolics than traditional varieties. The selection for a reduced degree of browning in commercial varieties has resulted probably in the indirect selection of materials with lower concentrations of phenolics (Prohens et al., 2005).

If we compare the results obtained by Whitaker and Stommel (2003) for the concentration of hydroxycinnamic conjugates for seven commercial varieties of eggplant with those of Stommel and Whitaker (2003) for 97 eggplant germplasm accessions 
grown in the same conditions, the germplasm materials have, as a mean, a concentration more than 50\% greater than the commercial varieties, which agrees with our results.

Sources of variation for high phenolic concentration can be found among common eggplant materials. However, the highest concentration of phenolics has been found in one accession of the related gboma eggplant, which suggests that this species could contribute to the genetic improvement of the concentration of phenolics in cultivated eggplant. However, the fact that the hybrids between $S$. melongena and $S$. macrocarpon have a reduced fertility (Bletsos et al., 2004) restricts its use to a longterm breeding program. Stommel and Whitaker (2003) tested only one accession of $S$. macrocarpon and found low values for phenolic acid contents in this species. This apparent discrepancy is probably attributable to the small number of accessions of $S$. macrocarpon involved in the two studies, and indicates that a considerable diversity must also exist in this species. Apart from $S$. macrocarpon, other species might be useful for the improvement of the quantitative and qualitative content of phenolics in S. melongena. For example, there is variation among species and varieties in the types and amounts of different phenolic acid conjugates, and this might have a bearing on the nutritional value or health benefits. In this respect, Stommel and Whitaker (2003) found that accessions of $S$. anguivi Lam. and $S$. incanum L. had higher concentrations of total phenolics than common eggplant, but also had a high percentage of unusual caffeic acid conjugates.

Some phenolics have a bitter taste (Macheix et al., 1990). However, the bitterness and "off" flavor of some eggplant varieties seems to be incited by saponins and glycoalkaloids and not by the phenolic compounds characteristic of eggplant (Aubert et al., 1989).

Although there is variation among varieties for the concentration in ascorbic acid, the content in this antioxidant is, as a mean, 27 times lower than that of phenolics. This much lower concentration, together with the fact that chlorogenic acid and ascorbic acid have similar antioxidant activities (Kim et al., 2002; Triantis et al., 2005), demonstrates that phenolics and, in particular, chlorogenic acid account for most of the antioxidant capacity of eggplant. Therefore, a breeding program directed at enhancing the antioxidant capacity of eggplant by increasing the ascorbic acid concentration would produce limited results. Furthermore, the narrow-sense heritability of ascorbic acid concentration is lower than that of phenolics.

Consumers and the industry prefer varieties with a luminous white color (Prohens et al., 2005). We have found a wide variation in the distance of the fruit flesh color to the pure white among the materials studied, and surprisingly there are many landraces that have a flesh color that is closer to the pure white than commercial varieties. As occurs in other solanaceous crops (Haynes et al., 1996), the flesh color is highly heritable and, in consequence, the exploitation of the variation present in landraces could lead to new commercial varieties with a more luminous white flesh color. Because the main phenolics of the eggplant fruit flesh are colorless (Macheix et al., 1990), the whiteness of the recently cut flesh is not correlated to the phenolic concentration, allowing the development of highly luminous white-flesh varieties with high phenolic concentration from materials that have no presence of chlorophylls in the flesh. The fact that the ascorbic acid concentration is positively correlated with the distance to the $b^{*}$ (i.e., to yellow) color parameter might be related to the rapid oxidation of ascorbic acid to give pale-yellow dehydroascorbic acid (Rouet-Mayer et al., 1990; Schuler, 1990).

Color parameters based on the change of color coordinates of cut surfaces of the fruit have been useful previously to measure the browning-related traits in eggplant (Sapers and Douglas, 1987). In the current study we found considerable differences among varieties for degree of browning and color difference. Commercial hybrid and nonhybrid varieties have lower mean degree of browning and color difference values than the landraces. This is probably the result of the selection made for reduced browning in the breeding programs. Degree of browning and color difference have high heritability, which means that to obtain offspring with a low degree of browning or color difference, parents should also have low values for these traits. As in many other crops, the degree of browning and color difference are positively correlated with the phenolic concentration (Amiot et al., 1992; Hansche and Boynton, 1986). However, the values of the correlation coefficients are moderate, and the phenolic concentration accounts for only $12 \%$ and $23 \%$ of the variation in these traits. Therefore, it seems possible to develop varieties with high concentrations of phenolics and reduced fruit flesh color evolution. Both traits (degree of browning and color difference) are obtained from the same color parameters $\left(\mathrm{L}^{*}, \mathrm{a}^{*}\right.$, and $\left.\mathrm{b}^{*}\right)$, and they are easy to calculate and provide complementary information. Therefore, to make a selection we recommend the simultaneous use of both parameters to have a better evaluation of the change in color. Ascorbic acid, which has antibrowning properties because it reduces enzymatically formed $o$-quinones to their precursor diphenols (Macheix et al., 1990), does not show any correlation with either degree of browning or color difference in eggplant. This is probably because of the very low concentrations of ascorbic acid in the eggplant fruit compared with the concentration of phenolics. Regarding the $\mathrm{pH}$, which also has an influence on the activity of polyphenol oxidases (Yoruk and Marshall, 2003), it does not show a correlation with either degree of browning or color difference. In the range of $\mathrm{pH}$ observed in our investigation, the activity of the eggplant polyphenol oxidase does not vary much (Dogan et al., 2002; Pérez-Gilabert and GarcíaCarmona, 2000). Other factors, like a different polyphenol oxidase activity among different varieties (Concellón et al., 2004) or other cellular factors, like the size of cells and interstitial spaces, which may differ among different varieties of a given species (Gould et al., 1990), may have a role in browning and color evolution of the fruit flesh.

In conclusion, our work shows that by using the variation present in the eggplant materials, it should be possible to select and develop new varieties with an increased concentration of phenolics and with a moderate degree of browning, similar to that of some currently successful commercial varieties. In this respect, some varieties with a high content of phenolics and a moderate degree of browning and color difference, like ANS24 and Thai Round Green, could be sources of variation of interest to achieve these objectives. As has occurred with other crops, like the tomato (Rodríguez-Burruezo et al., 2005), some sacrifice in perfect appearance may be acceptable by some consumers if nutritional value is increased. Because commercial varieties of eggplant have lost nutritional value compared with traditional varieties, modern breeding programs should take into account nutritional value as an additional breeding objective. 


\section{Literature Cited}

Aldrich, J. 1995. Correlations genuine and spurious in Pearson and Yule. Stat. Sci. 10:364-376.

Amiot, M.J., M. Tacchini, S. Aubert, and J. Nicolas. 1992. Phenolic composition and browning susceptibility of various apple cultivars at maturity. J. Food Sci. 57:958-962.

Ano, G., Y. Hebert, P. Prior, and C.M. Messiaen. 1991. A new source of resistance to bacterial wilt of eggplants obtained from a cross: Solanum aethiopicum L. $\times$ Solanum melongena L. Agronomie 11: 555-560.

Aubert, S., M.C. Daunay, and E. Pochard. 1989. Saponsides stéroidiques de l'aubergine (Solanum melongena L.) I. Intérêt alimentaire, méthodologie d'analyse, localisation dans le fruit. Agronomie 9:641-651.

Baixauli, C. 2001. Berenjena, p. 104-108. In: F. Nuez and G. Llácer (eds.). La horticultura española. Ediciones de Horticultura, Reus, Spain.

Bletsos, F., D. Roupakias, M. Tsaktsira, and A. Scaltsoyjannes. 2004. Production and characterization of interspecific hybrids between three eggplant (Solanum melongena L.) cultivars and Solanum macrocarpon L. Sci. Hort. 101:11-21.

Cao, G., E. Sofic, and R.L. Prior. 1996. Antioxidant capacity of tea and common vegetables. J. Agr. Food Chem. 44:3426-3431.

Concellón, A., M.C. Añón, and A.R. Chaves. 2004. Characterization and changes in polyphenol oxidase from eggplant fruit (Solanum melongena L.) during storage at low temperature. Food Chem. 88:17-24.

Daunay, M.C. and R.N. Lester. 1988. The usefulness of taxonomy for Solanaceae breeders, with special reference to the genus Solanum and to Solanum melongena L. (eggplant). Capsicum Eggplant Newsl. 7:70-79.

Daunay, M.C., S. Aubert, A. Frary, S. Doganlar, R.N. Lester, G. Barendse, G. van der Weerden, J.W. Hennart, J. Haanstra, F. Dauphin, and E. Jullian. 2004. Eggplant (Solanum melongena) fruit colour: Pigments, measurements and genetics. Proc. XIIth EUCARPIA Mtg. Capsicum Eggplant. p. 108-116.

Daunay, M.C., R.N. Lester, and G. Ano. 1997. Les aubergines, p. 83107. In: A. Charrier, M. Jacquot, S. Hamon, and D. Nicolas (eds.). L'amélioration des plantes tropicales. Cirad et Orstom, Montpellier, France.

Dogan, M., O. Arslan, and S. Dogan. 2002. Substrate specificity, heat inactivation and inhibition of polyphenol oxidase from different aubergine cultivars. Int. J. Food Sci. Technol. 37:415-423.

Gisbert, C., J. Prohens, and F. Nuez. 2006. Efficient regeneration in two potential new crops for subtropical climates, the scarlet (Solanum aethiopicum) and gboma (S. macrocarpon) eggplants. N.Z. J. Crop Hort. Sci. 34:55-62.

Gould, K.S., K.R.W. Hammett, and S. Steinhagen. 1990. Mechanism of bruise resistance in pepino (Solanum muricatum) fruit. Sci. Hort. 66:155-161.

Hallard, J. 1996. L'aubergine au Japon. PHM Revue Horticole 374: 55-56.

Hansche, P.E. and B. Boynton. 1986. Heritability of enzymatic browning in peaches. HortScience 21:1194-1197.

Haynes, K.G., J.B. Sieczka, M.R. Henninger, and D.L. Fleck. 1996. Clone $\times$ experiment interactions for yellow-flesh intensity in tetraploid potatoes. J. Amer. Soc. Hort. Sci. 121:175-177.

Kim, D.O., K.W. Lee, H.J. Lee, and C.Y. Lee. 2002. Vitamin C equivalent capacity (VCEAC) of phenolic phytochemicals. J. Agr. Food Chem. 50:3713-3717.
Lester, R.N. and S.M.Z. Hasan. 1991. Origin and domestication of the brinjal eggplant, Solanum melongena, from S. incanum, in Africa and Asia, p. 369-387. In: J.G. Hawkes, R.N. Lester, M. Nee, and N. Estrada (eds.). Solanaceae III: Taxonomy, chemistry, evolution. Linnean Society of London, London.

Macheix, J.J., A. Fleuriet, and J. Billot. 1990. Fruit phenolics. CRC Press, Boca Raton, FL.

Niggeweg, R., A.J. Michael, and C. Martin. 2004. Engineering plants with increased levels of the antioxidant chlorogenic acid. Nat. Biotechnol. 22:746-754.

Pérez-Gilabert, M. and F. García-Carmona. 2000. Characterization of catecholase and cresolase activities of eggplant polyphenol oxidase. J. Agr. Food Chem. 48:695-700.

Polignano, G.B., G. Laghetti, B. Margiotta, and P. Perrino. 2004. Agricultural sustainability and underutilized crop species in southern Italy. Plant Genet Resources Characterization Utilization 2:29-35.

Prohens, J., J.E. Muñoz, A. Rodríguez-Burruezo, and F. Nuez. 2005. Mejora genética de la berenjena. Vida Rural. 52-56.

Ramírez, E.C., J.R. Whitaker, and V.M. Virador. 2002. Polyphenol oxidase, p. 509-523. In: J.R. Whitaker, A.G.J. Voragen, and D.W.S. Wong (eds.). Handbook of food enzymology Marcel Dekker, New York.

Rodríguez-Burruezo, A., J. Prohens, S. Roselló, and F. Nuez. 2005. "Heirloom" varieties as sources of variation for the improvement of fruit quality in greenhouse-grown tomatoes. J. Hort. Sci. Biotechnol. 80:453-460.

Rouet-Mayer, M.A., J. Ralambosoa, and J. Philippon. 1990. Role of oquinones and their polymers in the enzymic browning of apples. Phytochemistry 29:435-440.

Sakata, Y. and R.N. Lester. 1997. Chloroplast DNA diversity in brinjal eggplant (Solanum melongena) and related species. Euphytica 97:295-301.

Sapers, G.M. and F.W. Douglas. 1987. Measurement of enzymatic browning at cut surfaces and in juice of raw apple and pear fruits. J. Food Sci. 52:1258-1262.

Sawa, T., M. Nakao, T. Akaike, K. Ono, and H. Maeda. 1998. Alkylperoxyl radical-scavenging activity of various flavonoids and other phenolic compounds: Implications for the anti-tumor-promoter effect of vegetables. J. Agr. Food Chem. 47:397-402.

Schuler, P. 1990. Natural antioxidants exploited commercially, p. 99170. In: B.J.F. Hudson (ed.). Food antioxidants. Elsevier Science Publishers, Barking, Essex, UK.

Singleton, V.L. and J.A. Rossi. 1965. Colorimetry of total phenolics with phosphomolybdic phosphotungstic acid reagents. Amer. J. Enol. Viticult. 16:144-158.

Stommel, J.R. and B.D. Whitaker. 2003. Phenolic acid composition of eggplant fruit in a germplasm core subset. J. Amer. Soc. Hort. Sci. 128:704-710.

Triantis, T., A. Stelakis, D. Dimotikali, and K. Papadopoulos. 2005. Investigations on the antioxidant activity of fruit and vegetable aqueous extracts on superoxide radical anion using chemiluminiscence techniques. Anal. Chim. Acta 536:101-105.

Whitaker, B.D. and J.R. Stommel. 2003. Distribution of hydroxycinnamic acid conjugates in fruit of commercial eggplant (Solanum melongena L.) cultivars. J. Agr. Food Chem. 51:3448-3454.

Wricke, G. and W. Weber. 1986. Quantitative genetics and selection in plant breeding. W. de Gruyter, Berlin.

Yoruk, R. and M.R. Marshall. 2003. Physicochemical properties and function of plant polyphenol oxidase: A review. J. Food Biochem. 27:361-422. 